\title{
Multinational enterprises and the Sustainable Development Goals: what do we know and how to proceed?
}

\author{
Ans Kolk, Arno Kourula and Niccolò Pisani*
}

Multinational enterprises (MNEs) can play an important role in the implementation of the Sustainable Development Goals (SDGs). This article examines what we know about their participation in implementing the SDGs and their impact, both positive and negative, on people, the planet, prosperity and peace as identified in the United Nations (UN) 2030 Agenda. To this end, we review the research published in the main international business journals on five key SDGs that represent these "four Ps", grouped into three categories: (1) poverty and inequality, (2) energy and climate change, and (3) peace. We summarize the findings of the 61 relevant studies and subsequently explore the UN's "fifth P", partnership, both in terms of published research on MNEs and the SDGs, and in terms of a collaborative agenda to help address the large challenges of the 2030 Agenda. In view of the relatively limited research on MNEs and SDGs thus far, academic institutions and international business scholars in particular are well-positioned to offer important insights about the role of business in supporting the SDGs, for which we offer suggestions, also in relation with other key actors.

\section{Introduction}

The Sustainable Development Goals (SDGs) are a set of 17 goals with 169 accompanying targets that set out quantitative and qualitative objectives across the social, economic and environmental dimensions of sustainable development to be achieved by 2030. As "Transforming our world: The 2030 agenda for sustainable

\footnotetext{
* Note: Authors are listed in alphabetical order. Ans Kolk (corresponding author) is a professor at the University of Amsterdam Business School, Netherlands. Contact: akolk@uva.nl, www.anskolk.eu. Arno Kourula is at the University of Amsterdam Business School and the Aalto University School of Business. Contact: A.E.Kourula@uva.nl. Niccolò Pisani is at the University of Amsterdam Business School. Contact: N.Pisani@uva.nl.
} 
development", the resolution adopted by the UN General Assembly (UN, 2015, p. 1), put it: "This agenda is a plan of action for people, planet and prosperity. It also seeks to strengthen universal peace in larger freedom.... All countries and all stakeholders, acting in collaborative partnership, will implement this plan." The SDGs have already resonated strongly in the international policy debate and attracted considerable academic attention, especially in the realm of development studies and sustainability science (see e.g. Oldekop et al., 2016, and the thematic issues of Current Opinion in Environmental Sustainability, February 2017, and International Environmental Agreements, June 2016). However, the SDGs' impact on multinational enterprises (MNEs) is still unclear and they have been relatively underexposed in international business (IB) research. In this article, we examine what we do know about MNEs and the SDGs to explore possible next steps and help set a collaborative research agenda, involving IB scholars, on these crucial policy goals.

Our analysis is based on a focused review of how IB research has explored key themes within the SDGs. We follow the main "Ps" identified in the preamble of the UN document (UN, 2015, p. 2). Their relevance for the study of MNEs was underlined by Kolk (2016), who developed a preliminary framework linking key IB concepts to the SDGs and firms' activities. ${ }^{1}$ As shown in figure 1, sustainable development encompasses a focus on people, the planet, peace and prosperity as an even broader composite, all to be realized through partnership. Following this approach, we have selected key goals: poverty and inequality (SDGs 1 and 10, broadly about people and prosperity), energy and climate change (SDGs 7 and 13, broadly about the planet), and peace (SDG 16, specifically about peace). This analysis is presented in the next section, which starts with an explanation of the methodology followed for our focused review. The last section offers perspectives on a collaborative agenda, in which we also reflect on SDG 17, creating partnerships for realizing the goals.

Kolk's (2016) framework drew on the original essential elements from UN (2014, p. 16), which distinguished people, planet, prosperity, justice and dignity as well as partnership, which can be seen as a key enabling mechanism to realize the goals. In the preamble of the 2015 document (UN, 2015, p. 2), peace replaced justice and dignity, as part of a broader rephrasing and repositioning of the components, which is the approach we also adopted in this article. 


\section{Figure 1. Preliminary Framework for Analyzing MNEs' Impact on Sustainable} Development

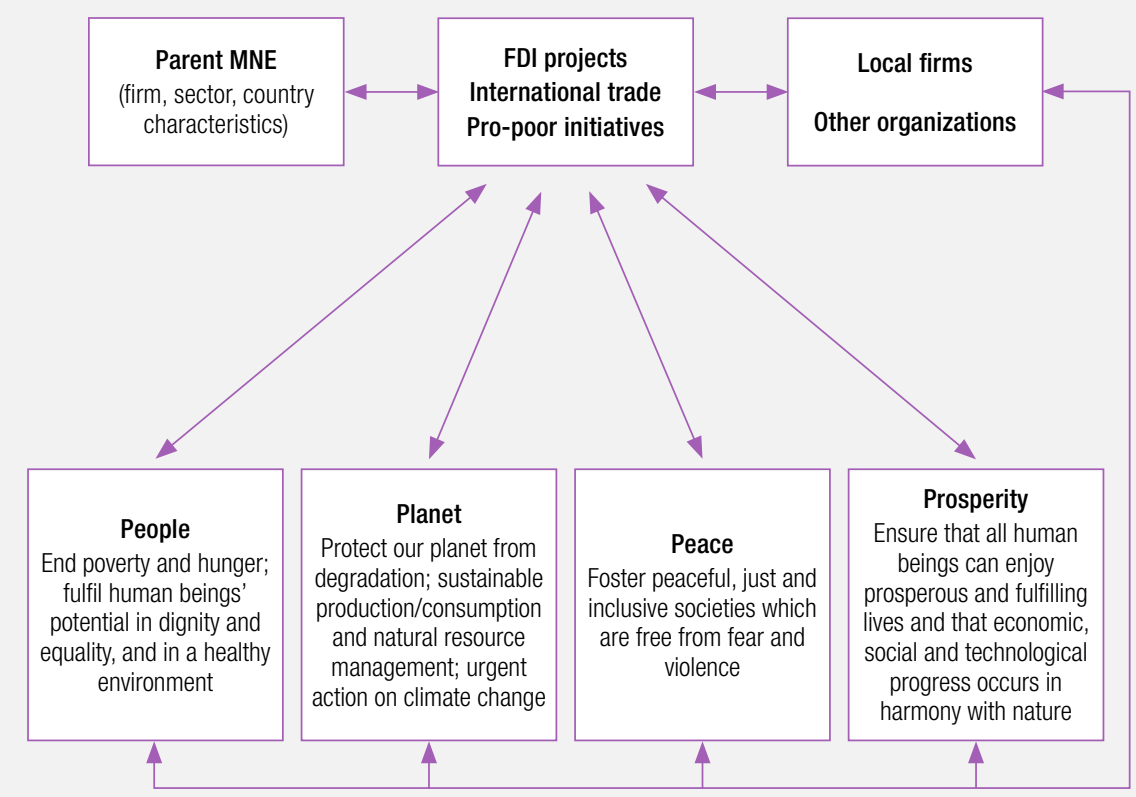

Source: Adapted from Kolk (2016, p. 31); as in the original, the upper part was inspired by Meyer (2004, p. 261) and the lower part derived from UN (2015, p. 2).

\section{International business and the Sustainable Development}

\section{Goals}

To assess what we know so far about the above-mentioned SDGs from an IB scholarship perspective, we conducted a systematic search of relevant articles in key IB academic journals. To undertake such search, we considered articles that were published in peer-reviewed academic journals, excluding other types of publications such as book reviews or conference proceedings. We restricted our selection of journals to six main journals in the IB field, considered as most relevant for the topic of our article and identified in previous literature reviews precisely focused on IB topics: the Journal of International Business Studies, Journal of World Business, Global Strategy Journal, Management International Review, Journal of International 
Management, and International Business Review. ${ }^{2}$ We made use of the Thomson Reuters Web of Knowledge and EBSCOhost Business Source Premier databases to search for articles from the selected journals. In our search, we considered the period ranging from January 1985 up to and including December 2016, in keeping with our intention to cover all of the literature on the topic; in total this encompassed more than 6,000 articles.

As generally is done in literature reviews (Aguinis and Glavas, 2012; Doh and Lucea, 2013; Pisani, 2009; Pisani et al., 2017), we ran a keyword search on the titles, abstracts and keywords provided by authors. The possibility of using standard Boolean operators enabled us to create the following unique search algorithm that we used to identify relevant articles: "inequality" OR "poverty" OR "poor" OR "base of the pyramid" OR "bottom of the pyramid" OR "BOP" OR "energy" OR "climate change" OR "global warming" OR "peace" OR "war" OR "political conflict" OR "armed conflict" OR "violent conflict" OR "terrorism". The keyword search yielded 127 articles that we read to determine whether they ought to be included in our final sample of articles. This led us to identify 61 articles that we considered relevant contributions for the purposes of our review. In the following subsections we review all of them, grouped according to the selected SDGs and themes.

\section{Poverty and Inequality}

IB research on poverty and inequality can be categorized into four broad themes: trade and inequality, MNE operations in developing countries, business at the base of the pyramid and microfinance. The two former themes deal with international trade and foreign direct investment, while the latter two are forms of pro-poor initiatives (see figure 1). Table 1 summarizes the key findings in IB research on poverty and inequality, and references all 27 articles pertaining to this stream of research.

Within the broad theme of trade and inequality, early descriptive and conceptual papers from the 1980s and 1990s laid the foundation for a discussion about the social impacts of international trade (see Behrman, 1985; Nalen, 1985; and Schmidheiny, 1992). More recently, Judge et al. (2014) explored the relationship

\footnotetext{
2 IB review articles usually include the Journal of International Business Studies, Journal of World Business and Management International Review and often also the International Business Review (e.g. Chan, Fung and Leung, 2006; Kolk and Van Tulder, 2010; Kumar and Kundu, 2004). We also considered the Journal of International Management (e.g. Treviño, Mixon, Funk and Inkpen, 2010) and the most recent addition to the field, the Global Strategy Journal (e.g. Tüselmann, Sinkovics and Pishchulov, 2016). We did not include the marketing-oriented journals International Marketing Review and Journal of International Marketing (as done by e.g. Xu, Yalcikaya and Seggie, 2008) as our experience, corroborated by a preliminary keyword search on these journals, shows that they pay less attention to the SDG-type of research that is key to this article (Kolk and Rivera-Santos, 2016).
} 


\section{Table 1. Summary of Key Themes and IB Studies on Poverty and Inequality}

\section{POVERTY AND INEQUALITY}

\begin{tabular}{|c|c|c|}
\hline Key themes & References & Key findings \\
\hline $\begin{array}{l}\text { Trade and } \\
\text { inequality } \\
\text { (No. articles: } 7 \text { ) }\end{array}$ & $\begin{array}{l}\text { Behrman (1985) } \\
\text { De Lange (2013) } \\
\text { Judge, Fainshmidt and } \\
\text { Brown (2014) } \\
\text { Nalen (1985) } \\
\text { Roy and Goll (2014) } \\
\text { Schmidheiny (1992) } \\
\text { Seyoum (2006) }\end{array}$ & $\begin{array}{l}\text { - Cross-national direct investment supports the development of } \\
\text { economic ties and a growing community of interests, making it } \\
\text { possible to address critical global problems and potentially leading } \\
\text { to a one-world economy (Behrman, 1985). } \\
\text { - Diasporas can support the rebalancing of global inequalities } \\
\text { (De Lange, 2013). } \\
\text { - Specific configurations of national business systems (including } \\
\text { lower power distance, better training systems and higher state } \\
\text { expenditures) are associated with relatively high levels of equitable } \\
\text { wealth creation, while others are not (Judge et al., 2014). } \\
\text { - In the mid-1980s, private investment in third world development } \\
\text { was described both as a market opportunity and as a project to } \\
\text { improve quality of lives and develop a prosperous and peaceful } \\
\text { world (Nalen, 1985). } \\
\text { - Cultural practices predict national-level sustainability; specifically, } \\
\text { a gender-egalitarian culture positively influences human } \\
\text { development, as does GDP and the economic growth rate } \\
\text { (Roy and Goll, 2014). } \\
\text { - Since its foundation, the Business Council for Sustainable } \\
\text { Development (BCSD) promoted liberal trade and international } \\
\text { agreements as ways to achieve economic growth and address } \\
\text { environmental issues (Schmidheiny, 1992). } \\
\text { - The Generalized System of Preferences has a significant and } \\
\text { positive effect on beneficiary exports from developing countries to } \\
\text { the United States (Seyoum, 2006). }\end{array}$ \\
\hline
\end{tabular}




\section{Table 1. Summary of Key Themes and IB Studies on Poverty and Inequality} (continued)

\section{POVERTY AND INEQUALITY}

\begin{tabular}{|c|c|c|}
\hline Key themes & References & Key findings \\
\hline $\begin{array}{l}\text { MNE operations } \\
\text { in developing } \\
\text { countries } \\
\text { (No. articles: 10) }\end{array}$ & $\begin{array}{l}\text { Chelekis and Mudambi } \\
\text { (2010) } \\
\text { Fortanier and Van Wijk } \\
\text { (2010) } \\
\text { Ghauri and Rao (2009) } \\
\text { Guth (2009) } \\
\text { Hill and Mudambi } \\
\text { (2010) } \\
\text { Husted (2013) } \\
\text { Levy (2007) } \\
\text { Musteen, Rhyne and } \\
\text { Zheng (2013) } \\
\text { Van de Vliert (2003) } \\
\text { Yamin and Sinkovics } \\
\text { (2009) }\end{array}$ & $\begin{array}{l}\text { - By leveraging local micro-entrepreneurship to compete with local } \\
\text { firms, MNEs can develop direct sales channels to remote areas } \\
\text { with positive local economic and social outcomes (Chelekis and } \\
\text { Mudambi, 2010). } \\
\text { - Although MNEs' entry into developing countries can have a positive } \\
\text { employment impact, it may also have a negative impact through the } \\
\text { poaching of talented employees of local firms (Fortanier and Van } \\
\text { Wijk, 2010). } \\
\text { - Several policy options and increased partnerships can mitigate } \\
\text { pharmaceutical companies' trade-off between preserving incentives } \\
\text { for innovation while making drugs accessible at affordable prices to } \\
\text { the poor (Ghauri and Rao, 2009). } \\
\text { - Five key trends are impacting MNEs: growth between and within } \\
\text { regions, increasing consumer demand among the very poor in } \\
\text { emerging markets, technological innovation, globalization of labor } \\
\text { markets, and increasing access to information and knowledge } \\
\text { (Guth, 2009). } \\
\text { - Entrepreneurship in emerging economies faces three specific } \\
\text { processes of spillover and catch up, brokering and bottom up } \\
\text { (Hill and Mudambi, 2010). } \\
\text { - Nonmarket research in global strategy should aim to first } \\
\text { infrastructure (Yamin and Sinkovics, 2009). } \\
\text { normatively determine what MNE responsibilities should be and } \\
\text { then strive to understand how MNEs can better manage their social } \\
\text { and environmental impacts (Husted, 2013). } \\
\text { - International business scholarship and constructs can help to make } \\
\text { global trade and MNEs' strategies supportive of development, } \\
\text { especially when orienting towards Millennium Development Goals } \\
\text { (Levy, 2007). } \\
\text { - A firm's reputation can constrain its actions in uncertain } \\
\text { environments such as least developed countries (Musteen et al., } \\
\text { - Overpaying employees is more prevalent in developing countries } \\
\text { to hat have a negative impact on the development } \\
\text { - 2003). }\end{array}$ \\
\hline
\end{tabular}




\section{Table 1. Summary of Key Themes and IB Studies on Poverty and Inequality} (concluded)

\section{POVERTY AND INEQUALITY}

\begin{tabular}{|c|c|c|}
\hline Key themes & References & Key findings \\
\hline $\begin{array}{l}\text { Business at } \\
\text { the base of the } \\
\text { pyramid (BOP) } \\
\text { (No. articles: 6) }\end{array}$ & $\begin{array}{l}\text { Acosta, Kim, Melzer, } \\
\text { Mendoza and Thelen } \\
\text { (2011) } \\
\text { Gold, Hahn and } \\
\text { Seuring (2013) } \\
\text { London and Hart } \\
\text { (2004) } \\
\text { Rivera-Santos and } \\
\text { Rufin (2010) } \\
\text { Schuster and } \\
\text { Holtbrügge (2012) } \\
\text { Sinkovics, Sinkovics } \\
\text { and Yamin (2014) }\end{array}$ & $\begin{array}{l}\text { - Geographical market heat maps can determine where the greatest } \\
\text { challenges and opportunities lie at the BOP (Acosta et al., 2011). } \\
\text { - Applying sustainable supply chain management to BOP projects } \\
\text { can complement economic, social and environmental dimensions of } \\
\text { sustainability (Gold et al., 2013). } \\
\text { - BOP strategies that focus on leveraging the strengths of local } \\
\text { market conditions (using non-traditional partners, co-inventing } \\
\text { custom solutions and building local capacity) outperform strategies } \\
\text { that rely on overcoming weaknesses (London and Hart, 2004). } \\
\text { - BOP and top of the pyramid interorganizational networks differ } \\
\text { significantly, having important implications for MNEs active in BOP } \\
\text { environments (Rivera-Santos and Rufin, 2010). } \\
\text { - To develop knowledge of the BOP, MNEs need to go beyond local } \\
\text { manufacturing and production facilities (Schuster and Holtbrügge, } \\
\text { 2012). } \\
\text { - Social value creation forms an integral part of entrepreneurship at } \\
\text { the BOP, despite several constraints (Sinkovics et al., 2014). }\end{array}$ \\
\hline $\begin{array}{l}\text { Microfinance } \\
\text { (No. articles: 4) }\end{array}$ & $\begin{array}{l}\text { Ault (2016) } \\
\text { Bruton, Khavul and } \\
\text { Chavez (2011) } \\
\text { Mersland, Randoy and } \\
\text { Strom (2011) } \\
\text { Serrano-Cinca and } \\
\text { Gutierrez-Nieto (2014) }\end{array}$ & $\begin{array}{l}\text { - The commercialization of microfinance contributes to less inclusivity } \\
\text { (i.e. microfinance institutions increasingly targeting wealthier clients } \\
\text { at the detriment of the poor), but lower levels of state fragility } \\
\text { decrease the pressure to switch to wealthier clients (Ault, 2016). } \\
\text { - Microloan borrowers who are future oriented, have decision-making } \\
\text { power and actively manage their relationships tend to be able to } \\
\text { create high-performing ventures that generate employment for } \\
\text { those outside their immediate family (Bruton et al., 2011). } \\
\text { - International influence (initiator, directorship, debt and networks) } \\
\text { has a strong impact on the performance of microfinance institutions } \\
\text { (Mersland et al., 2011). } \\
\text { - Microfinance institutions face mission drift, i.e. pressure to change } \\
\text { from a non-profit to a commercial venture (Serrano-Cinca and } \\
\text { Gutierrez-Nieto, 2014). }\end{array}$ \\
\hline
\end{tabular}


between national business systems and inequality. Specifically, they show that lower power distance, better training systems and higher state expenditures are associated with relatively high levels of equitable wealth creation. In a broad analysis of the relationship between cultural practices and sustainability, Roy and Goll (2014) find that a culture of gender egalitarianism supports human development, understood as a combination of income, health and education. Finally, De Lange (2013) argues that diasporas can play an important role in the rebalancing of global inequalities, and Seyoum (2006) claims that trade policies such as the generalized system of preferences have benefited exports from developing countries to the United States.

Whereas trade and inequality studies take an institutional approach, using the national level of analysis, several studies have explored MNE operations in developing countries specifically. IB scholars have examined a broad array of topics, including the role and impact of a good reputation for MNEs when operating in developing countries (Musteen, Rhyne and Zheng, 2013), employee compensation (Van de Vliert, 2003), recruitment of local talent (Fortanier and Van Wijk, 2010), the development of basic infrastructure (Yamin and Sinkovics, 2009), access to drugs (Ghauri and Rao, 2009), and the utilization of micro-entrepreneurs as partners (Chelekis and Mudambi, 2010). Introductory essays (Husted, 2013) and more general reviews of entrepreneurship in emerging economies (Hill and Mudambi, 2010) and broader trends in MNE participation in developing countries in the context of globalization (Guth, 2009; Levy, 2007) have also appeared. Although IB as a field can generally be seen as promoting international trade, it is interesting to note that studies have also explored the negative consequences of MNE activities in developing countries, both for firms and for society. For instance, Musteen et al. (2013) argue that a high reputation can become a burden for a firm when operating in least developed countries; Yamin and Sinkovics (2009) demonstrate how MNE strategies can have a negative impact on basic infrastructure in developing countries; and Fortanier and Van Wijk (2010) show that while MNEs tend to bring jobs to developing countries, they also can simultaneously poach talent from local companies. All of these studies have been published fairly recently and within a period of a few years. Thus, we argue that the impacts of MNEs in developing countries need much more scholarly attention.

Continuing with the theme of MNE operations in developing countries, several recent studies have been framed specifically as examining business at the base of the pyramid (BOP) and/or microfinance. The abbreviation "BOP" has become a popular label to describe business development in the base of the global income pyramid, i.e. very-low-income environments (see Kolk, Rivera-Santos and Rufin, 2014). One of the early articles on the BOP in IB was London and Hart's (2004) description of strategies in low-income markets. The authors suggest that strategies focusing on leveraging the strengths of local market conditions (using non-traditional partners, co-inventing custom solutions and building local capacity) outperform strategies relying on overcoming weaknesses. Since then, contributions to the broader BOP 
literature in IB journals include studies on MNEs' adaptation strategies (Schuster and Holtbrügge, 2012), development of networks (Rivera-Santos and Rufin, 2010), implementation of sustainable supply chain measures (Gold, Hahn and Seuring, 2013) and overall value creation in BOP environments (Sinkovics, Sinkovics and Yamin, 2014). Acosta et al. (2011) also provide the tool of market heat maps to pinpoint opportunities for business in developing so-called inclusive markets.

Finally, the microfinance theme has also received some attention in IB, including more specific topics of mission drift (i.e. struggling between for-profit and not-for-profit) of microfinance institutions (Serrano-Cinca and Gutierrez-Nieto, 2014), the negative societal impacts of commercialization (Ault, 2016), the impact of international influence including international initiators, directorship, debt and affiliations and networks (Mersland, Randoy and Strom, 2011), as well as the behaviour of microloan borrowers (Bruton, Khavul and Chavez, 2011). Especially impressive are studies using extensive data sets, such as Ault's (2016) data on lending practices of almost 2,700 microfinance institutions in 123 countries over a long period of time. We can clearly see that microfinance has become interesting to IB scholars only recently and hope that the practices related to this type of poverty reduction approach are further studied and critically evaluated in the future, although pro-poor initiatives entail much more than microfinance alone.

\section{Energy and Climate Change}

In terms of energy and climate change, we see only moderate research interest in IB journals, which is quite surprising given the importance of the topic and the much larger literature outside IB. The relevant IB studies identified using our methodology have been published fairly recently and deal with four key themes. We categorize literature based on particular stakeholder groups: MNEs, governments, entrepreneurs and consumers (see table 2, which offers an overview of the key findings in IB research on energy and climate change and includes the references to all 16 articles we identified as relevant contributions to this area of research).

An early study on MNEs, climate change and energy (Poduska, Forbes and Bober, 1992) indicates that environmental considerations were already viewed as central to business strategy at the beginning of the 1990s. We currently see that MNEs deal with many tensions (e.g. home versus host country requirements) as well as global isomorphic forces (Pinkse and Kolk, 2012a), yet IB research has given only limited attention to the tension associated with the standardization versus local adaptation of strategies on energy and climate change. Kolk and Pinkse (2008) show how firms can tackle issues such as climate change and develop advantages specific to "green" firms. Finally, when describing corporate citizenship initiatives to tackle climate change, Shinkle and Spencer (2012) show how automobile industry firms use similar themes across an industry with differences in implementation. 


\section{Table 2. Summary of Key Themes and IB Studies on Energy and Climate Change}

\section{ENERGY AND CLIMATE CHANGE}

\begin{tabular}{|c|c|c|}
\hline Key themes & References & Key findings \\
\hline $\begin{array}{l}\text { MNES } \\
\text { (No. articles: 4) }\end{array}$ & $\begin{array}{l}\text { Kolk and Pinkse } \\
\text { (2008) } \\
\text { Pinkse and Kolk } \\
\text { (2012a) } \\
\text { Poduska, Forbes } \\
\text { and Bober (1992) } \\
\text { Shinkle and } \\
\text { Spencer (2012) }\end{array}$ & $\begin{array}{l}\text { - Important environmental issues can give MNEs the opportunity to develop } \\
\text { "green" firm-specific advantages and reconfigure them for profit, growth } \\
\text { and survival (Kolk and Pinkse, 2008). } \\
\text { - MNEs need to find a balance between their institutional embeddedness in } \\
\text { home, host and supranational contexts (Pinkse and Kolk, 2012a). } \\
\text { - Environmental considerations have become a central part of business } \\
\text { planning (Poduska et al., 1992). } \\
\text { - When describing their corporate citizenship initiatives to tackle climate } \\
\text { change, MNEs use similar themes across an industry with differences in } \\
\text { implementation (Shinkle and Spencer, 2012). }\end{array}$ \\
\hline $\begin{array}{l}\text { Governments } \\
\text { (No. articles: 6) }\end{array}$ & $\begin{array}{l}\text { Bucheli and } \\
\text { Aguilera (2010) } \\
\text { Duncan (1992) } \\
\text { Foell (1992) } \\
\text { French (1990) } \\
\text { Romilly (2007) } \\
\text { Westin (1992) }\end{array}$ & $\begin{array}{l}\text { - A government depending on a small political coalition will use oil rents } \\
\text { as a private good to be distributed to those close to the ruler, whereas a } \\
\text { government relying on broad coalitions will use oil rents as public goods to } \\
\text { be distributed among the population (Bucheli and Aguilera, 2010). } \\
\text { - In the early 1990s, limiting carbon emissions by strict regulation and tax } \\
\text { was not seen as realistic, as } 80 \% \text { of the world was living in poverty and } \\
\text { seen to need economic development (Duncan, 1992). } \\
\text { - Former centrally planned economies' energy systems were in need } \\
\text { of transition as a consequence of devastating environmental impacts } \\
\text { (Foell, 1992). } \\
\text { - Governments can implement various measures to curb air pollution, } \\
\text { including transportation policies to lessen dependence on automobiles } \\
\text { (French, 1990). } \\
\text { - Regional temperature-risk profiles can help companies adapt to climate } \\
\text { change (Romilly, 2007). } \\
\text { - In the early 1990s, the United States government was lagging behind in } \\
\text { addressing climate change (Westin, 1992). }\end{array}$ \\
\hline $\begin{array}{l}\text { Entrepreneurs } \\
\text { (No. articles: 1) }\end{array}$ & De Lange (2016) & $\begin{array}{l}\text { - Entrepreneurs can overcome institutional voids with strategies that support } \\
\text { the development of an institutional field (De Lange, 2016). }\end{array}$ \\
\hline $\begin{array}{l}\text { Consumers } \\
\text { (No. articles: 1) }\end{array}$ & $\begin{array}{l}\text { Grinstein and } \\
\text { Riefler (2015) }\end{array}$ & $\begin{array}{l}\text { - Cosmopolitan consumers demonstrate environmental concerns and can } \\
\text { be targeted by either highlighting global benefits or activating a local } \\
\text { identity (Grinstein and Riefler, 2015). }\end{array}$ \\
\hline $\begin{array}{l}\text { Overviews/ } \\
\text { reviews }\end{array}$ & $\begin{array}{l}\text { Guest (2010) } \\
\text { Kolk (2016) } \\
\text { Kolk and Van } \\
\text { Tulder (2010) } \\
\text { Macharzina (2000) }\end{array}$ & $\begin{array}{l}\text { - Four essential elements are included in the economics of sustainability in } \\
\text { the context of climate change: valuing the distant future, the uncertainty } \\
\text { and irreversibility of climate change, the difference between natural and } \\
\text { reproducible capital; management of the global 'commons' (Guest, 2010). } \\
\text { - Fifty years of IB research on social responsibility has addressed three key } \\
\text { themes: (green) environment; ethics, rights and responsibilities; poverty } \\
\text { and (sustainable) development (Kolk, 2016). } \\
\text { - MNEs are seen more and more as part of the solution - and not just the } \\
\text { problem - in IB research on corporate social responsibility (Kolk and Van } \\
\text { Tulder, 2010). } \\
\text { - MNEs can decrease turbulence in European energy markets by supporting } \\
\text { global and national reduction of energy consumption (Macharzina, 2000). }\end{array}$ \\
\hline
\end{tabular}


Early work by French (1990) describes how governments started putting in measures to curb air pollution. Foell (1992) described the devastating effects of former centrally planned economies and called for energy transitions. Similarly, Westin (1992) was calling on the United States government to accept the existence of global warming and implement measures to address the challenge. In contrast, Duncan (1992) argued that extensive environmental maintenance measures needed to be balanced with the appropriate allocation of resources to consumption and investment. More recent work has developed regional risk profiles (Romilly, 2007) and the outcomes of governments' use of coalitions (Bucheli and Aguilera, 2010). The latter study finds that relying on broader political coalitions of individuals and organizations leads to governments using oil rents to distribute wealth among the population instead of privately gaining from them. A study on entrepreneurship by De Lange (2016) provides insights on how they can overcome institutional voids by developing their own institutional fields. Finally, Grinstein and Riefler (2015) focus on a particular customer segment: the cosmopolitan consumer. The authors argue that they can be targeted by either highlighting global benefits or activating a local identity.

In addition to examining key stakeholders, several reviews have also appeared that deal, at least partially, with topic areas such as climate change and energy (e.g. Guest, 2010; Kolk, 2016). We underline the importance of more research on these themes (and the SDGs), which are crucial both for the future of so many MNEs as well as for the fate of developing countries and the poor (for further studies cf. Kolk, 2015; Kolk and Van den Buuse, 2012).

\section{Peace}

The articles focused on peace can be further clustered into four broad themes based on the specific foci examined: relation between business and conflict, MNEs' responses to conflict, employees' reactions to conflict, and MNEs and terrorism. Table 3 summarizes the key findings in IB research on peace and contains the references to all 18 articles pertaining to this stream of research.

The first cluster, relation between business and conflict, focuses on the very relationship between economic variables and political conflict. Studies on this relationship started to appear in economics and political science in the 1980s and led to the formation of an entire segment of literature on this topic (see for instance the seminal article by Polachek (1980), who showed that trade and conflict are inversely related). Yet, the volume of IB research that has focused on this issue has been rather limited until now (Henisz, Mansfield and Von Glinow, 2010). The first contribution in the 61 articles is Lee (1993), who investigated the relative importance of political instability and economic variables on perceived country creditworthiness and showed that both variables explain variation in credit ratings. Specifically, the frequency of regime changes and armed conflict significantly affect the creditworthiness of - especially - 


\section{Table 3. Summary of Key Themes and IB Studies on Peace}

\section{PEACE}

\begin{tabular}{|c|c|c|}
\hline Key themes & References & Key findings \\
\hline $\begin{array}{l}\text { Relation between } \\
\text { business and } \\
\text { conflict } \\
\text { (No. articles: } 6 \text { ) }\end{array}$ & $\begin{array}{l}\text { Dai, Eden and Beamish } \\
\text { (2013) } \\
\text { Henisz, Mansfield and } \\
\text { Von Glinow (2010) } \\
\text { Lee (1993) } \\
\text { Li and Vashchilko } \\
\text { (2010) } \\
\text { Ramos and Ashby } \\
\text { (2013) } \\
\text { Retzky (1995) }\end{array}$ & $\begin{array}{l}\text { - Greater exposure to geographically defined threats reduces the } \\
\text { likelihood of MNEs' foreign subsidiary survival in host countries } \\
\text { afflicted by political conflict. In addition, both the concentration and } \\
\text { the dispersion of other firms affect survival, and the effects are } \\
\text { dependent not only on where the firm is geographically located but } \\
\text { also on the type of other firms located in the geographic proximity } \\
\text { (Dai et al., 2013). } \\
\text { - Greater international commerce fosters cooperation, at least } \\
\text { as a mean tendency. Country-level, sector-level and firm-level } \\
\text { contingencies affect the strength and nature of the relation between } \\
\text { conflict and economic exchange (Henisz et al., 2010). } \\
\text { - Both political instability and economic variables are taken into } \\
\text { account in evaluating country creditworthiness; the frequency } \\
\text { of regime changes and armed conflict, both proxies for political } \\
\text { instability, affect credit ratings (Lee, 1993). } \\
\text { - Interstate alliances and political-military conflict influence bilateral } \\
\text { investment flows by changing both government policies towards } \\
\text { international business and investor expectations of political risk. } \\
\text { Whereas military conflict reduces bilateral investment, security } \\
\text { alliances increase it (Li and Vashchilko, 2010). } \\
\text { - Investor home-country experience with organized crime does not } \\
\text { ameliorate the negative effect that organized crime has on foreign } \\
\text { direct investment. Crime in host locations is positively associated } \\
\text { with investment from high-crime countries (Ramos and Ashby, } \\
\text { 2013). } \\
\text { - The trader's axiom: with stability, spreads narrow. Unforeseen } \\
\text { external forces create uncertainty and widen spreads, which is why } \\
\text { business takes the absence of these events into consideration when } \\
\text { judging whether to trade or invest. This concept has even greater } \\
\text { significance when applied to the Middle East (Retzky, 1995). }\end{array}$ \\
\hline $\begin{array}{l}\text { MNEs' responses } \\
\text { to conflict } \\
\text { (No. articles: 3) }\end{array}$ & $\begin{array}{l}\text { Barnes and Oloruntoba } \\
\text { (2015) } \\
\text { Jallat and Shultz } \\
\text { (2011) } \\
\text { Oetzel and Getz (2012) }\end{array}$ & $\begin{array}{l}\text { - Cross-sector partnerships between government and firms can be a } \\
\text { useful response to mitigate the terrorist threats in global maritime } \\
\text { supply chains (Barnes and Oloruntoba, 2015). } \\
\text { - In order to manage a crisis properly, MNEs should be systematically } \\
\text { prepared before the crisis occurs through, for instance, the } \\
\text { establishment of a standardized crisis response plan; during the } \\
\text { crisis, subsidiaries should also try to take advantage of their being } \\
\text { part of a MNE network, for example, by leveraging the relevant } \\
\text { knowledge accumulated in headquarters or by taking advantage of } \\
\text { a corporate culture that can supersede crisis conditions in some } \\
\text { contexts (Jallat and Shultz, 2011). } \\
\text { - Stakeholder pressures influence the likelihood that firms will } \\
\text { respond to violent conflict. Local stakeholder pressure tends to } \\
\text { trigger a direct response; international stakeholder pressure an } \\
\text { indirect one (Oetzel and Getz, 2012). }\end{array}$ \\
\hline
\end{tabular}




\section{Table 3. Summary of Key Themes and IB Studies on Peace (concluded)}

\section{PEACE}

\begin{tabular}{|c|c|c|}
\hline Key themes & References & Key findings \\
\hline $\begin{array}{l}\text { Employees' } \\
\text { reactions to } \\
\text { conflict } \\
\text { (No. articles: 4) }\end{array}$ & $\begin{array}{l}\text { Bader and Berg (2013) } \\
\text { Bader, Berg and } \\
\text { Holtbrügge (2015) } \\
\text { Bader and Schuster } \\
\text { (2015) } \\
\text { Reade and Lee (2012) }\end{array}$ & $\begin{array}{l}\text { - Several terrorism-related stressors create a significant stress level } \\
\text { for the individual, causing negative work attitudes and attitudes } \\
\text { towards host-country nationals (disaffection) (Bader and Berg, } \\
\text { 2013). } \\
\text { - In terrorism-endangered countries, safety-related intrafamily tension } \\
\text { significantly impedes expatriates' work performance (Bader et al., } \\
\text { 2015). } \\
\text { - Large and diversified networks positively affect the psychological } \\
\text { well-being of expatriates. Moreover, a higher terrorism level per se } \\
\text { does not necessarily negatively affect the psychological well-being } \\
\text { of expatriates; however, the impact of expatriate social network } \\
\text { characteristics on psychological well-being is amplified (Bader and } \\
\text { Schuster, 2015). } \\
\text { - Employee sensitivity to ethno-political conflict is inversely related } \\
\text { to organizational commitment and has explanatory power beyond } \\
\text { the traditional predictors of organizational commitment (Reade and } \\
\text { Lee, 2012). }\end{array}$ \\
\hline $\begin{array}{l}\text { MNEs and } \\
\text { terrorism } \\
\text { (No. articles: 5) }\end{array}$ & $\begin{array}{l}\text { Branzei and Abdelnour } \\
\text { (2010) } \\
\text { Czinkota, Knight, } \\
\text { Liesch and Steen } \\
\text { (2005) } \\
\text { Czinkota, Knight, } \\
\text { Liesch and Steen } \\
\text { (2010) } \\
\text { Czinkota and } \\
\text { Ronkainen (2009) } \\
\text { Harvey (1993) }\end{array}$ & $\begin{array}{l}\text { - Terrorism conditions may create psychological incentives for } \\
\text { enterprise resilience, which may even yield more favourable } \\
\text { economic payoffs at higher levels of terrorism, especially for } \\
\text { informal entrepreneurs (Branzei and Abdelnour, 2010). } \\
\text { - Terrorism poses both direct and indirect threats to the operations } \\
\text { of the firm. It represents a market imperfection that increases } \\
\text { transaction costs and creates barriers to the free flow of goods, } \\
\text { affecting potential gains that would occur in the presence of } \\
\text { unhindered exchange (Czinkota et al., 2005). } \\
\text { - Terrorism threatens international business through its direct and } \\
\text { indirect effects. Although the scholarly literature on terrorism in } \\
\text { domains outside business is extensive, research within IB is still } \\
\text { limited (Czinkota et al., 2010). } \\
\text { - Firms and policymakers have a clear understanding that terrorism } \\
\text { is an ongoing phenomenon to be confronted. As such, it is one of } \\
\text { the issues that have significantly risen in importance in international } \\
\text { business (Czinkota and Ronkainen, 2009). } \\
\text { - Many companies do not have formal programs to deal with a } \\
\text { terrorist attack. Most of the firms that do have programs spend their } \\
\text { programs on security equipment and not on training executives and } \\
\text { their families (Harvey, 1993). }\end{array}$ \\
\hline
\end{tabular}


less developed countries, which are then found to face difficulties in respecting their debt obligations. Conflict harms the ability to attract funds and respect international obligations and thus negatively influences the ability of firms to grow and flourish. This is because the resulting low creditworthiness of the government negatively affects the creditworthiness of firms in that country. This notion is corroborated by the case of Israeli business and the benefits that it would be able to enjoy from peace in the Middle East as discussed by Retzky (1995).

More recently, Ramos and Ashby (2013) have examined the notion that conflict generated by organized crime has also a negative effect on foreign direct investment that is not weakened by foreign investors' home-country experience. The authors show that higher levels of organized crime in host environments are positively related with investments from high-crime countries, thus suggesting a heterogeneous firm response to organized crime. In addition, Dai et al. (2013) have recently contributed to this stream of research by examining the specific role of geography in the survival of MNEs' foreign subsidiaries in host environments afflicted by political conflict. Their study shows that greater exposure of the foreign subsidiary to geographically defined threats reduces the likelihood of its survival. Furthermore, the authors show that both concentration and dispersion with other firms affect the survival of firms, with the effect being dependent on not only where the firm is located (i.e. whether the zone is afflicted by a conflict) but also what other firms are nearby (i.e. with home-country peers or sister subsidiaries).

The second theme we identified is MNEs' responses to conflict. Jallat and Schults (2011) examine the case study of the Phoenicia hotel in Beirut, a member of the MNE InterContinental Hotels Group, and how it responded to the 2005 bombing that disrupted the tourism industry in Lebanon. The authors examine how this hotel, despite being directly affected by the bombings, managed to thrive in the face of this extreme crisis. Among the key factors that made this possible was the fact that the hotel managers had devoted time and resources to complete a crisis management plan before they experienced the event. The preparation of an ex-ante contingency plan had ensured that the firm was suitably prepared. Oetzel and Getz (2012) investigate over 450 MNEs operating in 80 countries to understand the factors that affect the likelihood of firms to respond to violent conflict. They show that whereas local stakeholder pressures are more likely to trigger a direct response to this type of conflict, international stakeholder pressures tend to incentivize a more indirect response.

The third theme entails studies on employees' reactions to conflict. Bader and Berg (2013) corroborate the notion that the presence of conflict heightens the stress levels of employees in general and, more specifically, of expatriates. Moreover, Bader et al. (2015) confirm that expatriates do not perform well when they face safetyrelated tensions that affect their own families; however, Bader and Schuster (2015) looked at expatriates' social networks and show that large and diversified networks contribute to the improved psychological well-being of expatriates who are relocated 
to terrorism-endangered countries. Reade and Lee (2012) examine organizational commitment in foreign-invested and local firms situated in an operating environment characterized by ethnopolitical conflict and its violent manifestations of civil war and terrorism. The authors show that employees' sensitivity to the conflict is inversely related to their firm's organizational commitment, thus suggesting the presence of an additional indirect cost faced by firms operating in such environments. Their analysis also shows that foreign-invested firms are relatively better equipped to manage this potential cost by maintaining a high level of perceived organizational support among their employees.

The fourth and final theme, MNEs and terrorism, focuses on the specific issue of terrorism, defined as "the premeditated, systematic threat or use of violence by subnational groups to attain a political, religious, or ideological objective through intimidation of a large audience" (Czinkota et al., 2010, p. 828) - and its impact on the operations of firms. The first contribution to this theme in our sample dates back to 1993, when Harvey examined United States-based MNEs' programs for managing terrorist attacks and found that less than $50 \%$ of the surveyed firms had formal procedures to deal with one and that those which did invested exclusively in security equipment rather than in training for employees. Nearly a decade later, Czinkota et al. (2005) offered a broader discussion on the direct and indirect threats of terrorism to the operations of firms and developed a series of general propositions on terrorism's link to management and marketing. In a 2010 Perspective article published in Journal of International Business Studies, Czinkota et al. further elaborated on this discussion and specifically examined the relation of terrorism and IB, developing a nuanced theoretical grounding for terrorism research in the IB field. The authors built on the extensive research done on political risk and argued that the approaches developed in the IB literature in relation to political risk hold relevance for firms in dealing with terrorism as well. Having said this, even though political risk and terrorism share some characteristics, they differ in various ways that make research focused on the specificities of terrorism necessary. Czinkota et al. (2010) thus offered a comprehensive agenda for future research. In the same issue focused on conflict, security and political risk, Branzei and Abdelnour (2010) and Li and Vashchilko (2010) also offered interesting insights on this topic - respectively on the paradox of enterprise emergence and persistence under extreme adversity, and on the role of interstate military conflict and security alliances on investor expectations of political risk.

Assessing the stream of studies linking terrorism to IB, we note that, despite the several fruitful directions offered in the perspective article by Czinkota et al. (2010), as of 28 April 2017, their work was cited by 27 articles in the Web of Science database, with many of these articles falling outside the specific realm of IB research. Therefore, we call explicit attention to this dearth of studies. As Czinkota et al. (2010, p. 826) appropriately put it "IB scholars are encouraged to offer useful perspectives 
and effective solutions that shed needed light on terrorism and help reduce its destructive effects for international business and multinational firms." We concur with the authors that the role of terrorism in IB must be better understood. To this end, additional scholarly research focused on terrorism and the IB landscape is much needed. Furthermore, it is highly salient that the very topic of peace has not become a stream of research within IB yet (and did not show up in any significant way in our search). This is all the more remarkable as "business for peace" and "peace through commerce" (terms often used interchangeably) have given risen to a multidisciplinary body of work (for a good overview, see Lenfant, 2016, and the symposium in the Academy of Management Perspectives, November 2015). This is thus another area that deserves further research attention.

\section{Collaborative agenda for the future}

Given the state of the art as reported in this article, this final section discusses possible next steps and what different parties may do, individually but especially jointly, in view of the huge challenges ahead. Interestingly, while partnership is a crucial component of the SDGs and has received ample academic and practitioner attention in a still growing stream of literature related to sustainability and corporate social responsibility (CSR), in our sample only a few studies focus on this fifth P (and thus SDG 17). Of the 127 articles that we derived from the original keyword search (see section 2) focused on themes within the other four Ps (people, planet, prosperity, peace), only 2 also contained the keyword "partnership" in the title, abstract or keywords provided by the authors. These two focused on the importance of respectively generating new partnerships between government and business at both the national and the international levels in an effort to mitigate terrorist threats in global maritime supply chains (Barnes and Oloruntoba, 2015), and establishing non-market partnerships with well-known organizations such as universities and research institutes as a way to achieve legitimacy for clean technology entrepreneurs (De Lange, 2016).

In the original full set of over 6,000 articles from the six journals over the 19852016 period, 58 came out when searching for the term partnership, but only 5 could be clearly associated with the notion of partnership intended as the fifth $\mathrm{P}$ (most of the retrieved articles mentioned the word "partnerships" when referring to firms' strategic alliances and joint ventures). The five articles that we identified as relevant covered different facets of the notion of partnership. Specifically, Ritvala et al. (2014) focus on three types of integration mechanisms (resource mechanisms, ideational and social mechanisms, and organizational mechanisms) that increase the likelihood of a successful creation of cross-sector partnerships between multinationals, governments and non-profit organizations. Bhanji and Oxley (2015) also centre their attention on cross-sector partnerships and their specific use to facilitate firms' implementation of corporate citizenship programs. In a similar vein 
to the work by De Lange (2016), Marano and Tashman (2012) and Kourula (2010) investigate multinationals' creation of partnerships with NGOs in their quest for social legitimacy. Finally, Mair and Martí (2006) assess social entrepreneurship research and only tangentially focus on the notion of partnership insofar as a stream of studies has framed the socially responsible practices of firms precisely in relation to their engagement in cross-sector partnerships.

Although our journal sample and keyword selection obviously suffer from the usual limitations, the fact that we found only a few articles on partnerships underscores how little the IB academic literature has addressed this topic thus far, because a broader search that includes management and CSR or sustainability journals would have yielded some more studies (Kourula, Pisani and Kolk, 2017). For example, Kolk and Lenfant (2015) provide insight into the literature on cross-sector collaboration in the business and the policy and development fields, to subsequently focus on partnerships for peace and development and thus set the stage for further research concerning fragile areas in particular. Their study and framework suggest ample opportunities for further investigation, focused on MNEs, not only regarding peace but also other SDGs. Partnerships for climate change have been studied empirically by, for example, Bulkeley et al. (2012) and Pinkse and Kolk (2012b). Here too, the dynamics of international business are not specifically investigated, and the explicit positioning within the whole SDG debate has been missing as well. Thus, from the partnership perspective, which emphasizes the added value of cross-sector collaboration to further the greater societal good, these examples show how some existing studies can provide a starting point for more in-depth research on MNEs and the SDGs. Likewise, discussions about the need for collaborative, sustainable business models has entered the management and environmental literature, but how these can be translated or transformed for firms that operate across borders, and especially in least developed countries, has hardly received attention.

All this means that there is a huge task ahead for IB scholars because they have specific foci and competences to help shed light on how to advance sustainable development involving international firms as key actors operating, and thus with the potential to play a role, in different geographical locations. Figure 1 provides a possible framework to help direct future research efforts, with the key IB elements summarized in the upper part. Although some of the components have been investigated already (especially the economic impact of foreign direct investment in developing countries), a coherent approach is needed involving the broad implications for sustainable development of MNEs' investments, trade and pro-poor (CSR) initiatives. Such research can be done for individual SDGs or for (parts of) the people, planet, peace and prosperity clusters. Our analysis here suggests that poverty and inequality as well as peace have been underexamined, despite their tremendous societal salience. Findings offered by future IB studies in these realms can be vital input for policymaking related to the SDGs. 
At the same time, IB scholars will need to partner to get their voices heard, as all too often the vast valley between academic knowledge and practical relevance remains uncrossed. This has to do with, inter alia, the nature of academia nowadays and the complex web of (especially UN) policymaking, which is very difficult to unravel for scholars working at universities and business schools. All actors have (over) loaded day-to-day schedules, which show huge differences in content and activities as well; thus, it is crucial to find targeted avenues for truly effective exchange of knowledge, i.e. without involving large numbers of meetings. We see this effort as one that should be initiated or developed by those in charge of furthering the SDG 2030 agenda, but it will require active participation by and willingness from researchers to translate and communicate their findings in the most appropriate way at such occasions when given the opportunity. This means not only personal but also institutional commitment to make a real and substantial contribution. For example, individuals must be brave enough to take partly uncharted and sometimes risky research routes, which may often involve reaching out to other (sub)disciplines. It is necessary that their institutions recognize the value of such efforts, even if (perceived) "high-quality journal" output cannot be realized immediately, and that they provide time and funding if needed. Such recognition would be easier to achieve if work on MNEs and the SDGs becomes more widespread and common in reputable IB journals. That also implies that interested researchers would not be burdened with browsing non-field journals to learn about the most relevant debates and the state of the art, a task that is in fact hard to achieve, given the growing specialization and rapid expansion of the number of outlets across the board.

As shown in this article, we have still quite a way to go in IB to make this happen, despite all the interesting studies done so far. Although our analysis of 61 articles published in IB journals has offered only a partial overview of how the field has addressed the four "Ps" (people, planet, prosperity and peace), the studies themselves reveal that IB scholarship is particularly well positioned to support our understanding of and action towards sustainable development. Earlier work from the 1980s and 1990s related to the themes of the SDGs emphasized macro-level developments, but later IB research has focused more on the organizational level. The key insights from IB on sustainable development have come and will continue to come from an in-depth examination of the roles of firms, which other disciplines cannot do to the same extent although they can help focus attention on notions such as inclusive development and human well-being (Kourula et al., 2017). Although lack of data has often been mentioned as a key barrier to further research, a recent review article on IB and international CSR (Pisani et al., 2017) gives a helpful overview of a range of sources and notes that they are often used in only a few articles and that more frequent use, preferably in a pooled manner, might be an effective way to address this problem. Perhaps international organizations such as UNCTAD could play a role in merging existing databases or could provide comprehensive overviews of (new) data collection efforts relevant to MNEs and the SDGs. 
Overall, MNEs can clearly have an important impact on sustainable development, both through their negative social and environmental externalities and, as they are increasingly portrayed, as a provider of solutions. We should acknowledge that MNEs have had a central role in creating the challenges we now face and that sustainable transitions are unlikely to take place in a smooth manner. IB studies have dealt with the selected SDGs in a fairly broad way, with the requisite focus on trade and multinational firms. Nonetheless, it is obvious that MNEs will not aim to achieve the SDGs alone but in partnerships - hence, the fifth P. While IB has a tendency to examine multinationals, a variety of other actors - such as intergovernmental organizations, national governments, cities, the whole range of nongovernmental organizations including grassroots organizations and trade unions, the media, small and medium-sized local firms, and sustainable entrepreneurs - are central to dealing with the SDGs. Thus, various forms of partnerships and dialogue are necessary, as well as a critical assessment of the possibility of all actors to get their voices heard. Despite all the complexities and challenges involved, we look forward to this exciting journey for research, teaching, business practice and policymaking and to making a further contribution.

\section{References}

Acosta, P., Kim, N., Melzer, I., Mendoza, R. U., and Thelen, N. (2011). Business and human development in the base of the pyramid: Exploring challenges and opportunities with market heat maps. Journal of World Business, 46(1), 50-60.

Aguinis, H., and Glavas, A. (2012). What we know and don't know about corporate social responsibility a review and research agenda. Journal of Management, 38(4), 932-968.

Ault, J. K. (2016). An institutional perspective on the social outcome of entrepreneurship: Commercial microfinance and inclusive markets. Journal of International Business Studies, 47(8), 951-967.

Bader, B., and Berg, N. (2013). An empirical investigation of terrorism-induced stress on expatriate attitudes and performance. Journal of International Management, 19(2), 163-175.

Bader, B., Berg, N., and Holtbrügge, D. (2015). Expatriate performance in terrorism-endangered countries: The role of family and organizational support. International Business Review, 24(5), 849-860.

Bader, B., and Schuster, T. (2015). Expatriate social networks in terrorism-endangered countries: An empirical analysis in Afghanistan, India, Pakistan, and Saudi Arabia. Journal of International Management, 21(1), 63-77.

Barnes, P., and Oloruntoba, R. (2005). Assurance of security in maritime supply chains: Conceptual issues of vulnerability and crisis management. Journal of International Management, 11(4), 519-540.

Behrman, J. N. (1985). The future of international business and the distribution of benefits. Columbia Journal of World Business, 20(4), 15-22. 
Bhanji, Z., and Oxley, J. E. (2013). Overcoming the dual liability of foreignness and privateness in international corporate citizenship partnerships. Journal of International Business Studies, 44(4), 290-311.

Branzei, O., and Abdelnour, S. (2010). Another day, another dollar: Enterprise resilience under terrorism in developing countries. Journal of International Business Studies, 41(5), 804-825.

Bruton, G. D., Khavul, S., and Chavez, H. (2011). Microlending in emerging economies: Building a new line of inquiry from the ground up. Journal of International Business Studies, 42(5), 718-739.

Bucheli, M., and Aguilera, R. V. (2010). Political survival, energy policies, and multinational corporations. Management International Review, 50(3), 347-378.

Bulkeley, H., Andanova, L., Bäckstrand, K., Betsill, M., Compagnon, D., Duffy, R., Kolk, A., Hoffmann, M., Levy, D., Newell, P., Milledge, T., Paterson, M., Pattberg, P., and VanDeveer, S. (2012). Governing climate change transnationally: Assessing the evidence from a database of sixty initiatives. Environment and Planning C: Politics and Space, 30(4), 591-612.

Chan, J. C., Fung, H. G., and Leung, W. K. (2006). International business research: Trends and school rankings. International Business Review, 15, 317-338.

Chelekis, J., and Mudambi, S. M. (2010). MNCs and micro-entrepreneurship in emerging economies: The case of Avon in the Amazon. Journal of International Management, 16(4), 412-424.

Czinkota, M. R., Knight, G. A., Liesch, P. W., and Steen, J. (2010). Terrorism and international business: A research agenda. Journal of International Business Studies, 41(5), 826-843.

Czinkota, M. R., Knight, G. A., Liesch, P. W., and Steen, J. (2005). Positioning terrorism in management and marketing: Research propositions. Journal of International Management, 11(4), 581-604.

Czinkota, M. R., and Ronkainen, I. A. (2009). Trends and indications in international business. Management International Review, 49(2), 249-265.

Dai, L., Eden, L., and Beamish, P. W. (2013). Place, space and geographical exposure: Foreign subsidiary survival in conflict zones. Journal of International Business Studies, 44(6), 554-578.

De Lange, D. E. (2013). Embedded diasporas: Shaping the geopolitical landscape. Journal of International Management, 19(1), 14-25.

De Lange, D. E. (2016). Legitimation strategies for clean technology entrepreneurs facing institutional voids in emerging economies. Journal of International Management, 22(4), 403-415.

Doh, J. P., and Lucea, R. (2013). So close yet so far: Integrating global strategy and nonmarket research. Global Strategy Journal, 3, 171-194.

Duncan, N. E. (1992). The energy dimensions of sustainable development. Columbia Journal of World Business, 27(3/4), 164-173.

Foell, W. K. (1992). Energy management in Eastern Europe and the former USSR. Columbia Journal of World Business, 27(3/4), 174-185. 
Fortanier, F., and Van Wijk, J. (2010). Sustainable tourism industry development in sub-Saharan Africa: Consequences of foreign hotels for local employment. International Business Review, 19(2), 191-205.

French, H. F. (1990). Clearing the air: A global agenda. Columbia Journal of World Business, 25(1/2), 64-82.

Ghauri, P. N., and Rao, P. M. (2009). Intellectual property, pharmaceutical MNEs and the developing world. Journal of World Business, 44(2), 206-215.

Gold, S., Hahn, R., and Seuring, S. (2013). Sustainable supply chain management in "base of the pyramid" food projects - A path to triple bottom line approaches for multinationals? International Business Review, 22(5), 784-799.

Grinstein, A., and Riefler, P. (2015). Citizens of the (green) world? Cosmopolitan orientation and sustainability. Journal of International Business Studies, 46(6), 694-714.

Guest, R. (2010). The economics of sustainability in the context of climate change: An overview. Journal of World Business, 45(4), 326-335.

Guth, W. D. (2009). Developing new avenues for growth: Challenges presented by five trends in the global environment. Journal of International Management, 15(3), 251-261.

Harvey, M. G. (1993). A survey of corporate programs for managing terrorist threats. Journal of International Business Studies, 24(3), 465-478.

Henisz, W. J., Mansfield, E. D., and Von Glinow, M. A. (2010). Conflict, security and political risk: International business in challenging times. Journal of International Business Studies, 41(5), 759-764.

Hill, T. L., and Mudambi, R. (2010). Far from Silicon Valley: How emerging economies are re-shaping our understanding of global entrepreneurship. Journal of International Management, 16(4), 321-327.

Husted, B. W. (2013). Global environment and social strategy. Global Strategy Journal, 3(2), 195-197.

Jallat, F., and Shultz, C. J. (2011). Lebanon: From cataclysm to opportunity-Crisis management lessons for MNCs in the tourism sector of the Middle East. Journal of World Business, 46(4), 476-486.

Judge, W. Q., Fainshmidt, S., and Brown, J. L. (2014). Which model of capitalism best delivers both wealth and equality? Journal of International Business Studies, 45(4), 363-386.

Kolk, A. (2015). The role of international business in clean technology transfer and development. Climate Policy, 15(1), 170-176.

Kolk, A. (2016). The social responsibility of international business: From ethics and environment to CSR and sustainable development. Journal of World Business, 51(1), 23-34.

Kolk, A., and Lenfant, F. (2015). Partnerships for peace and development in fragile states: Identifying missing links. Academy of Management Perspectives, 29(4), 422-437.

Kolk, A., and Pinkse, J. (2008). A perspective on multinational enterprises and climate change: Learning from "an inconvenient truth"? Journal of International Business Studies, 39(8), 1359-1378. 
Kolk, A., and Van den Buuse, D. (2012). In search of viable business models for development: Sustainable energy in developing countries. Corporate Governance: International Journal of Business in Society, 12(4), 551-567.

Kolk, A., and Van Tulder, R. (2010). International business, corporate social responsibility and sustainable development. International Business Review, 19(2), 119-125.

Kolk, A., and Rivera-Santos, M. (2016). The state of research on Africa in business and management. Insights from a systematic review of key international journals. Business and Society, doi: 10.1177/0007650316629129.

Kolk, A., Rivera-Santos, M., and Rufin, C. R. (2014). Reviewing a decade of research on the "base/bottom of the pyramid" (BOP) concept. Business and Society, 53(3), 338-377.

Kourula, A. (2010). Corporate engagement with non-governmental organizations in different institutional contexts - A case study of a forest products company. Journal of World Business, 45(4), 395-404.

Kourula, A., Pisani, N., and Kolk, A. (2017). Corporate sustainability and inclusive development: Highlights from international business and management research. Current Opinion in Environmental Sustainability, 24(1), 14-18.

Kumar, V., and Kundu, S. K. (2004). Ranking the international business schools: Faculty publication as the measure. Management International Review, 44, 213-228.

Lee, S. H. (1993). Relative importance of political instability and economic variables on perceived country creditworthiness. Journal of International Business Studies, 24(4), 801-812.

Lenfant, F. (2016). On business, conflict and peace: Interaction and collaboration in Central Africa. University of Amsterdam, PhD thesis. https://pure.uva.nl/ws/files/2750024/179301_ Lenfant_Thesis_complete_aangepast_.pdf.

Levy, B. (2007). The interface between globalization, trade and development: Theoretical issues for international business studies. International Business Review, 16(5), 594-612.

Li, Q. A., and Vashchilko, T. (2010). Dyadic military conflict, security alliances and bilateral FDI flows. Journal of International Business Studies, 41(5), 765-782.

London, T., and Hart, S. L. (2004). Reinventing strategies for emerging markets: Beyond the transnational model. Journal of International Business Studies, 35(5), 350-370.

Mair, J., and Martí, I. (2006). Social entrepreneurship research: A source of explanation, prediction, and delight. Journal of World Business, 41(1), 36-44.

Marano, V., and Tashman, P. (2012). MNE/NGO partnerships and the legitimacy of the firm. International Business Review, 21(6), 1122-1130.

Mersland, R., Randoy, T., and Strom, R. O. (2011). The impact of international influence on microbanks' performance: A global survey. International Business Review, 20(2), 163-176.

Musteen, M., Rhyne, L., and Zheng, C. C. (2013). Asset or constraint: Corporate reputation and MNCs; involvement in the least developed countries. Journal of World Business, 48(3), 321-328.

Macharzina, K. (2000). European energy. Management International Review, 40(4), 303-305.

Nalen, C. A. (1985). The role of private investment in third world development. Columbia Journal of World Business, 20(4), 59-72. 
Oetzel, J., and Getz, K. (2012). Why and how might firms respond strategically to violent conflict? Journal of International Business Studies, 43(2), 166-186.

Oldekop, J. A., Fontana, L. B., Grugel, J., Roughton, N., Adu-Ampong, E. A., Bird, G. K., Dorgan, A., Vera Espinoza, M. A., Wallin, S., Hammett, D., Agbarakwe, E., Agrawal, A., Asylbekova, N., Azkoul, C., Bardsley, C., Bebbington, A. J., Carvalho, S., Chopra, D., Christopoulos, S., Crewe, E., Dop, M. C., Fischer, J., Gerretsen, D., Glennie, J., Gois, W., Gondwe, M., Harrison, L. A., Hujo, K., Keen, M., Laserna, R., Miggiano, L., Mistry, S., Morgan, R. J., Raftree, L. L., Rhind, D., Rodrigues, T., Roschnik, S., Senkubuge, F., Thornton, I., Trace, S., Ore, T., Valdés, R. M., Vira, B., Yeates, N., and Sutherland, W. J. (2016). 100 key research questions for the post-2015 development agenda. Development Policy Review, 34(1), 55-82.

Oetzel, J., and Getz, K. (2012). Why and how might firms respond strategically to violent conflict? Journal of International Business Studies, 43(2), 166-186.

Pinkse, J., and Kolk, A. (2012a). Multinational enterprises and climate change: Exploring institutional failures and embeddedness. Journal of International Business Studies, 43(3), 332-341.

Pinkse, J., and Kolk, A. (2012b). Addressing the climate change-sustainable development nexus: The role of multi-stakeholder partnerships. Business and Society, 51(1), 176-210.

Pisani, N. (2009). International management research: Investigating its recent diffusion in top management journals. Journal of Management, 35(2), 199-218.

Pisani, N., Kourula, A., Kolk, A., and Meijer, R. (2017). How global is international CSR research? Insights and recommendations from a systematic review. Journal of World Business, doi: 10.1016/j.jwb.2017.05.003.

Poduska, R., Forbes, R., and Bober, M. A. (1992). The challenge of sustainable development. Columbia Journal of World Business, 27(3/4), 286-291.

Polachek, S. W. (1980). Conflict and trade. Journal of Conflict Resolution, 24(1), 55-78.

Ramos, M. A., and Ashby, N. J. (2013). Heterogeneous firm response to organized crime: Evidence from FDI in Mexico. Journal of International Management, 19(2), 176-194.

Reade, C., and Lee, H. J. (2012). Organizational commitment in time of war: Assessing the impact and attenuation of employee sensitivity to ethnopolitical conflict. Journal of International Management, 18(1), 85-101.

Retzky, A. (1995). Peace in the Middle East: What does it really mean for Israeli business? Columbia Journal of World Business, 30(3), 26-32.

Ritvala, T., Salmi, A., and Andersson, P. (2014). MNCs and local cross-sector partnerships: The case of a smarter Baltic Sea. International Business Review, 23(5), 942-951.

Rivera-Santos, M., and Rufin, C. (2010). Global village vs. small town: Understanding networks at the base of the pyramid. International Business Review, 19(2), 126-139.

Romilly, P. (2007). Business and climate change risk: A regional time series analysis. Journal of International Business Studies, 38(3), 474-480.

Roy, A., and Goll, I. (2014). Predictors of various facets of sustainability of nations: The role of cultural and economic factors. International Business Review, 23(5), 849-861. 
Schmidheiny, S. (1992). The business logic of sustainable development. Columbia Journal of World Business, 27(3/4), 18-24.

Schuster, T., and Holtbrügge, D. (2012). Market entry of multinational companies in markets at the bottom of the pyramid: A learning perspective. International Business Review, 21(5), 817-830.

Serrano-Cinca, C., and Gutierrez-Nieto, B. (2014). Microfinance, the long tail and mission drift. International Business Review, 23(1), 181-194.

Seyoum, B. (2006). US trade preferences and export performance of developing countries: Evidence from the generalized system of preferences. International Business Review, 15(1), 68-83.

Shinkle, G. A., and Spencer, J. W. (2012). The social construction of global corporate citizenship: Sustainability reports of automotive corporations. Journal of World Business, 47(1), 123-133.

Sinkovics, N., Sinkovics, R. R., and Yamin, M. (2014). The role of social value creation in business model formulation at the bottom of the pyramid - Implications for MNEs? International Business Review, 23(4), 692-707.

Treviño, L. J., Mixon Jr., F. G., Funk, C. A., and Inkpen, A. C. (2010). A perspective on the state of the field: International business publications in the elite journals as a measure of institutional and faculty productivity. International Business Review, 19(4), 378-387.

Tüselmann, H., Sinkovics, R. R., and Pishchulov, G. (2016). Revisiting the standing of international business journals in the competitive landscape. Journal of World Business, 51(4), 487-498.

United Nations (2014). The road to dignity by 2030: Ending poverty, transforming all lives and protecting the planet. Synthesis report of the Secretary-General on the post-2015 sustainable development agenda. UN General Assembly, A/69/700, 4 December.

United Nations (2015). Resolution adopted by the General Assembly on 25 September 2015. A/RES/70/1. https://sustainabledevelopment.un.org/post2015/transformingourworld.

Van de Vliert, E. (2003). Thermoclimate, culture and poverty as country-level roots of workers' wages. Journal of International Business Studies, 34(1), 40-52.

Westin, R. A. (1992). Global climate change. Columbia Journal of World Business, 27(1), 76-85.

Yamin, M., and Sinkovics, R. R. (2009). Infrastructure or foreign direct investment? An examination of the implications of MNE strategy for economic development. Journal of World Business, 44(2), 144-157.

Xu, S., Yalcinkaya, G., and Seggie, S. H. (2008). Prolific authors and institutions in leading international business journals. Asia Pacific Journal of Management, 25, 189-207. 